\title{
In Vitro Regeneration of Parthenocarpic Cucumber (Cucumis sativus L.)
}

\author{
Ajay Bhardwaj*, T. Pradeepkumar and C. Varun Roch \\ Biotechnology Laboratory, Department of Olericulture, College of Horticulture, Kerala \\ Agricultural University, Vellanikkara-680656, Kerala, India \\ *Corresponding author
}

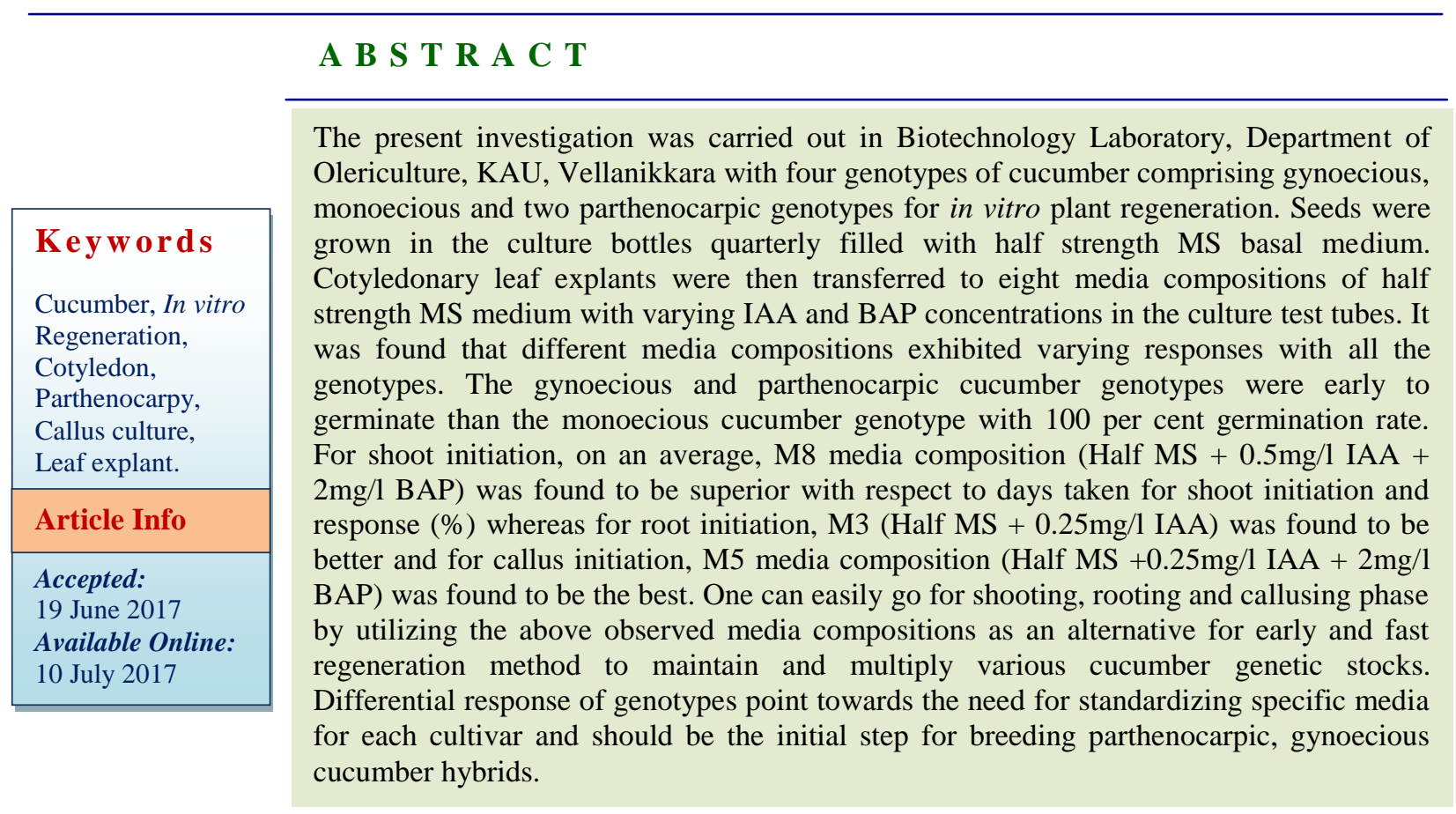

\section{Introduction}

Cucumber (Cucumis sativus L.), a popular vegetable crop of the family Cucurbitaceae, is rich in phosphorus, potassium and oxalic acid and is popularly used in salads. Of late, this crop is becoming popular in Kerala as it can be grown under polyhouse, rain shelter and open conditions. The polyhouse cultivation requires parthenocarpic cucumber and at present, farmers are depending on the seeds supply from multinational companies. Parthenocarpy is development of fruit in absence of fertilization or other stimulation.
It has the potential to increase yield, especially under unfavorable conditions, e.g. in protected cultivation. Moreover, parthenocarpic fruits (seedless) are firm and fleshier than seeded cucumbers.

Therefore, development of parthenocarpic cultivars is one of the most important targets in plant breeding (Wu et al., 2016). Breeding parthenocarpic cucumber types is not as a success in India and maintenance of parthenocarpic genetic material requires novel 
approaches such as in vitro culture (Mahmoud and Mokhtari, 2014).

Cucumber is extremely difficult to propagate vegetatively in in-vivo condition, and therefore, the development of in vitro micropropagation methods (regeneration system) would be very useful for its clonal multiplication (Mohiuddin et al., 2011). Moreover, the development of a rapid and efficient regenerating tissue culture system is a prerequisite for the introduction of novel genes into cucumber plants via genetic engineering. As induction of male flowers for the maintenance of parthenocarpic and gynoecious genotypes is a very cumbersome and time consuming method, in vitro regeneration could be used as a competent and alternative tool.

A good micropropagation protocol could reduce the cost of hybrid seed production, which accounts for 30 per cent of the total seedling cost (Konstas and Kintzios, 2003). The commercial application of in vitro techniques in cucurbitaceous taxa has been well demonstrated and the regeneration of plants has been reported from excised cotyledons, leaf explants (Stipp et al., 2001) and another culture (Kumar et al., 2003).

Most of the reports are on cotyledonary cultures in cucurbits, which describes indirect plant regeneration from the cotyledons developed from seed explants (Ugandhar et al., 2011) and somatic embryogenesis from leaf derived calli (Usmaan et al., 2011). Different media compositions have been reported for various set of variable conditions. Hence, the standardization of in vitro regeneration for cucumber genotypes viz., gynoecious, parthenocarpic and monoecious will be helpful for designing breeding programme and commercial propagation of especially parthenocarpic and gynoecious cucumber stocks.

\section{Materials and Methods}

The present study was conducted at Biotechnology laboratory, Department of Olericulture, Kerala Agricultural University, Vellanikkara in the year 2014-15. For conducting the study four genotypes of cucumber were included (Table 1). Three sex forms/types of cucumber viz., gynoecious, parthenocarpic and monoecious respectively were taken.

The study was carried out in two phases' namely in vitro seed germination and in vitro regeneration using cotyledonary explants. Details of these are given under following sub heads:

\section{In vitro seed germination and culture conditions}

The seeds of cucumber were washed in running tap water for three minutes and then washed repeatedly in double distilled water. The seeds were then soaked in mild detergent and $0.1 \mathrm{~g}$ Bavistin in $100 \mathrm{ml}$ water for 10 minutes and were rinsed with distilled water for 5 times. These were then sterilized in 50 per cent ethyl alcohol for five minutes and repeatedly washed in double distilled water for 3-4 times. The seeds were then surface sterilized with 0.05 per cent Mercuric chloride $\left(\mathrm{HgCl}_{2}\right)$ for five minutes and rinsed five times in sterile distilled water. The sterilized seeds were then placed on half strength MS basal medium (Murashige and Skoog, 1962) solidified with agar for germination in $250 \mathrm{ml}$ culture bottles, three seeds were cultured per bottle containing $30 \mathrm{ml}$ of medium. This was incubated in dark at $26{ }^{\circ} \mathrm{C}$ till it germinated and then transferred to cool-white-fluorescent light room and incubated at $24 \pm 2{ }^{\circ} \mathrm{C}$ and allowed to grow. The data were recorded for days to 50 per cent germination, days to 100 per cent germination and germination percentage. The plant after reaching a height 
of five centimeters was taken in an aseptic condition and cotyledons were excised using a sterile scalpel and cut into two leaf sections.

\section{Plant regeneration}

The seedling excised (cotyledons) explants were then placed on eight different media compositions of BAP and IAA in the test tubes of half strength MS medium containing $3 \% \mathrm{w} / \mathrm{v}$ sucrose (Table 2). The $\mathrm{pH}$ of the media was adjusted to $5.8 \pm 0.1$ with $1 \mathrm{~N} \mathrm{HCl}$ or $1 \mathrm{~N} \mathrm{NaOH}$ and then solidified with agar and autoclaved at $121^{\circ} \mathrm{C}$ at $15 \mathrm{psi}$ for $15-20$ minutes. Single cotyledonary leaf explants were inoculated in each culture tube and incubated at $25 \pm 2{ }^{\circ} \mathrm{C}$ under white fluorescent light for $16 \mathrm{hrs}$ light/ $8 \mathrm{hrs}$ dark period. The data were recorded for shoot, root and callus initiation along with response (\%) for consecutive three weeks.

\section{Results and Discussion}

In vitro response of seed culture and regeneration of monoecious, parthenocarpic and gynoecious cucumber genotypes are presented in the respective subheads:

\section{In vitro seed germination}

The seed germination was achieved in average three to four days of inoculation in half strength MS basal medium without any hormones with 100 per cent germination rate for all the genotypes used (Table 3; Figure 1). The genotype G1 (Gynoecious cucumber: EC 709119 or GY-14; 1.25 \pm 0.16 ) has taken minimum days for 50 per cent germination followed by the genotype G2 (Parthenocarpic cucumber: CS-130; 1.33 \pm 0.19$), \quad$ G4 (Parthenocarpic cucumber: CS-131; $1.58 \pm 0.21$ ) and G3 (Monoecious cucumber hybrid: L-04; $1.67 \pm 0.30$ ), respectively in the homogeneous set of conditions (Table 3 ). In case of days to 100 per cent germination, the genotype G1 (3.50 \pm 0.25$)$ has taken minimum days for germination followed by $\mathrm{G} 2$ $(3.50 \pm 0.50), \quad$ G3 $(3.75 \pm 0.14)$ and G4 $(4.00 \pm 0.50)$, respectively (Table 3 ). It can be concluded that the gynoecious and parthenocarpic cucumber genotypes were early to germinate than the monoecious types.

\section{Shoot initiation}

The shoot initiation (Figure 2) was achieved for all the genotypes in M8 media composition with 100 per cent response. M8 $(5.75 \pm 1.29)$ medium gave best result for days taken for shoot initiation followed by M3 $(8.83 \pm 1.93)$ and M1 (8.17 \pm 2.09$)$, respectively (Table 4). In addition, for the genotype G1, the three media compositions M8, M3 and M1 had shown 100 per cent response for shoot initiation. All the remaining composition failed for in vitro shooting

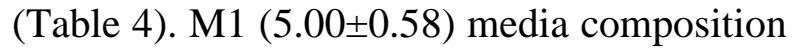
took minimum days for shooting followed by

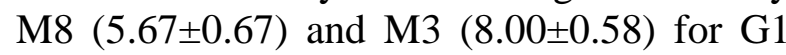
genotype whereas M8 media showed 100 per cent response with minimum days taken for shoot initiation in the genotypes, G2 $(4.67 \pm 0.67)$ and G3 $(3.33 \pm 0.33)$, respectively (Table 4). There was no response for M4 media composition in both the genotypes, G2 and $\mathrm{G} 3$, respectively. In case of monoecious cucumber hybrid (G4), M3 (4.67 \pm 0.33$)$ media gave best response in terms of minimum days taken for shoot initiation with 100 per cent response. It can be concluded that for gynoecious genotype, M1 media composition; for parthenocarpic genotype, M8 media composition; and for monoecious genotype, M3 media composition were superior to others (Table 4).

\section{Root initiation}

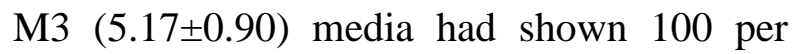
cent response for root initiation by taking minimum days while M2 had shown no response for all the genotypes used (Table 5). For gynoecious genotype, three media 
compositions were found to be 100 per cent responsive with less number of days taken in M3 (3.67 \pm 0.67$)$ followed by M8 (5.67 \pm 0.33$)$, whereas five media compositions failed to show any response (Table 5).

In the case of parthenocarpic genotype (G2), M1 (5.33 \pm 0.33$)$ followed by M3 (6.00 \pm 0.58$)$ took minimum days for root initiation with cent per cent response whereas for another parthenocarpic genotype (G3), M3 (3.67 \pm 0.33 ) exhibited 100 per cent response which was found to be superior to other media compositions for root initiation (Table 5). Monoecious genotype (G4) had shown 100 per cent response with M3 (7.33 \pm 0.33$)$ media composition and took less number of days for root initiation. It can be concluded that all the genotypes had shown 100 per cent rooting with M3 media composition (Figure 3) except for G2 which was better with M1 media composition (Table 5).

\section{Callus initiation}

Gynoecious genotype (G1) showed 100 per cent callus initiation with M5 $(9.00 \pm 0.58)$ followed by M7 (17.33 \pm 0.33$)$ media compositions and took minimum days for reaching callusing phase in comparison to others whereas M1 showed no response for callus initiation in the genotype G1 (Table 6; Figure 4). Parthenocarpic genotype (G2) was better for callusing in M5 (10.33 \pm 0.33$)$ media composition while another parthenocarpic genotype (G3) was better with M2 (6.33 \pm 0.33$)$ media composition showing 100 per cent response in the replications.

Table.1 Details of genotypes used

\begin{tabular}{lll}
\hline Genotype & Sex form/type & Variety \\
\hline G1 & Gynoecious cucumber & EC-709119 (GY-14) \\
G2 & Parthenocarpic cucumber & CS-130 \\
G3 & Parthenocarpic cucumber & CS-131 \\
G4 & Monoecious cucumber hybrid & L-04 \\
\hline
\end{tabular}

Table.2 Details of media composition

\begin{tabular}{llll}
\hline Media & Composition & Media & Composition \\
\hline M1 & Half MS (Basal Media) & M5 & Half MS + 0.25mg/l IAA + 2mg/l \\
M2 & Half MS + 2mg/l BAP & M6 & HaP \\
M3 & Half MS + 0.25mg/l IAA & M7 & Half MS + 0.5mg/l IAA \\
M4 & Half MS + 0.25mg/l IAA + 1mg/l BAP & M8 & Half MS + 0.5mg/l IAA + 1mg/l BAP \\
\hline
\end{tabular}

Table.3 In-vitro seed germination of cucumber genotypes

\begin{tabular}{cccc}
\hline Genotype & $\begin{array}{c}\text { Days taken for 50 per } \\
\text { cent germination* }\end{array}$ & $\begin{array}{c}\text { Days taken for 100 per } \\
\text { cent germination* }\end{array}$ & Germination (\%) \\
\hline G1 & $1.25 \pm 0.16$ & $3.50 \pm 0.25$ & 100 \\
G2 & $1.33 \pm 0.19$ & $3.50 \pm 0.50$ & 100 \\
G3 & $1.67 \pm 0.30$ & $3.75 \pm 0.14$ & 100 \\
G4 & $1.58 \pm 0.21$ & $4.00 \pm 0.50$ & 100 \\
\hline
\end{tabular}

'*' Data are Mean \pm Standard error, $\mathrm{n}=15$ 
Table.4 Effect of BAP and IAA for Shoot initiation from cotyledonary explants for different genotypes

\begin{tabular}{|c|c|c|c|c|c|c|c|c|c|c|}
\hline \multicolumn{2}{|r|}{ G1 } & \multicolumn{3}{|c|}{ G2 } & \multicolumn{2}{|l|}{ G3 } & \multicolumn{2}{|l|}{ G4 } & \multicolumn{2}{|c|}{ Average of all genotypes } \\
\hline & $\begin{array}{l}\text { Days taken for } \\
\text { shoot } \\
\text { initiation* }\end{array}$ & $\begin{array}{l}\text { Shoot } \\
\text { initiation } \\
\text { response }(\%)\end{array}$ & $\begin{array}{l}\text { Days taken } \\
\text { for shoot } \\
\text { initiation* }\end{array}$ & $\begin{array}{l}\text { Shoot initiation } \\
\text { response }(\%)\end{array}$ & $\begin{array}{l}\text { Days taken for } \\
\text { shoot } \\
\text { initiation* }\end{array}$ & $\begin{array}{l}\text { Shoot initiation } \\
\text { response }(\%)\end{array}$ & $\begin{array}{l}\text { Days taken for } \\
\text { shoot } \\
\text { initiation* }\end{array}$ & $\begin{array}{l}\text { Shoot } \\
\text { initiation } \\
\text { response }(\%)\end{array}$ & $\begin{array}{l}\text { Days taken for } \\
\text { shoot initiation* }\end{array}$ & $\begin{array}{l}\text { Shoot } \\
\text { initiation } \\
\text { response (\%) }\end{array}$ \\
\hline M1 & $5.00 \pm 0.58$ & 100.00 & $9.50 \pm 0.41$ & 66.67 & $4.67 \pm 0.33$ & 100.00 & $13.50 \pm 0.41$ & 66.67 & $8.17 \pm 2.09$ & 83.33 \\
\hline M2 & NR & 0.00 & $5.67 \pm 0.33$ & 100.00 & $12.00 \pm 0.58$ & 100.00 & NR & 0.00 & $8.83 \pm 2.24$ & 50.00 \\
\hline M3 & $8.00 \pm 0.58$ & 100.00 & $14.00 \pm 0.82$ & 66.67 & $8.67 \pm 0.67$ & 100.00 & $4.67 \pm 0.33$ & 100.00 & $8.83 \pm 1.93$ & 91.67 \\
\hline M4 & $8.50 \pm 0.41$ & 66.67 & NR & 0.00 & NR & 0.00 & $7.33 \pm 0.33$ & 100.00 & $7.92 \pm 0.41$ & 41.67 \\
\hline M5 & NR & 0.00 & $4.00 \pm 0.00$ & 100.00 & $4.50 \pm 0.41$ & 66.67 & $5.00 \pm 0.00$ & 66.67 & $4.50 \pm 0.25$ & 58.33 \\
\hline M6 & NR & 0.00 & $16.33 \pm 0.33$ & 100.00 & NR & 0.00 & $6.33 \pm 0.33$ & 100.00 & $11.33 \pm 3.54$ & 50.00 \\
\hline M7 & NR & 0.00 & $7.33 \pm 0.33$ & 100.00 & $12.67 \pm 0.88$ & 100.00 & NR & 0.00 & $10.00 \pm 1.89$ & 50.00 \\
\hline M8 & $5.67 \pm 0.67$ & 100.00 & $4.67 \pm 0.67$ & 100.00 & $3.33 \pm 0.33$ & 100.00 & $9.33 \pm 0.33$ & 100.00 & $5.75 \pm 1.29$ & 100.00 \\
\hline
\end{tabular}

Table.5 Effect of BAP and IAA for Root initiation from cotyledonary explants for different genotypes

\begin{tabular}{|c|c|c|c|c|c|c|c|c|c|c|}
\hline & \multirow{2}{*}{$\begin{array}{l}\text { G1 } \\
\text { Days taken for } \\
\text { root initiation* }\end{array}$} & \multicolumn{3}{|c|}{ G2 } & \multicolumn{2}{|l|}{ G3 } & \multicolumn{2}{|l|}{ G4 } & \multicolumn{2}{|c|}{ Average of all genotypes } \\
\hline & & $\begin{array}{l}\text { Root } \\
\text { initiation } \\
\text { response }(\%)\end{array}$ & $\begin{array}{l}\text { Days taken } \\
\text { for root } \\
\text { initiation* }\end{array}$ & $\begin{array}{l}\text { Root initiation } \\
\text { response }(\%)\end{array}$ & $\begin{array}{l}\text { Days taken for } \\
\text { root initiation* }\end{array}$ & $\begin{array}{l}\text { Root initiation } \\
\text { response }(\%)\end{array}$ & $\begin{array}{l}\text { Days taken for } \\
\text { root initiation* }\end{array}$ & $\begin{array}{l}\text { Root } \\
\text { initiation } \\
\text { response }(\%)\end{array}$ & $\begin{array}{l}\text { Days taken for } \\
\text { root initiation* }\end{array}$ & $\begin{array}{l}\text { Root initiation } \\
\text { response }(\%)\end{array}$ \\
\hline M1 & NR & 0.00 & $5.33 \pm 0.33$ & 100.00 & $12.00 \pm 0.82$ & 66.67 & $13.00 \pm 0.82$ & 66.67 & $10.11 \pm 2.08$ & 58.33 \\
\hline M2 & NR & 0.00 & NR & 0.00 & NR & 0.00 & NR & 0.00 & NR & NR \\
\hline M3 & $3.67 \pm 0.67$ & 100.00 & $6.00 \pm 0.58$ & 100.00 & $3.67 \pm 0.33$ & 100.00 & $7.33 \pm 0.33$ & 100.00 & $5.17 \pm 0.91$ & 100.00 \\
\hline M4 & NR & 0.00 & $13.00 \pm 0.00$ & 66.67 & NR & 0.00 & NR & 0.00 & $13.00 \pm 0.00$ & 16.67 \\
\hline M5 & NR & 0.00 & $8.00 \pm 0.00$ & 33.33 & $9.00 \pm 0.00$ & 66.67 & NR & 0.00 & $8.50 \pm 0.35$ & 25.00 \\
\hline M6 & $14.33 \pm 0.33$ & 100.00 & $12.33 \pm 0.33$ & 100.00 & $12.33 \pm 0.67$ & 100.00 & $15.00 \pm 0.82$ & 66.67 & $13.50 \pm 0.69$ & 91.67 \\
\hline M7 & NR & 0.00 & NR & 0.00 & $17.00 \pm 0.00$ & 33.33 & NR & 0.00 & $17.00 \pm 0.00$ & 8.33 \\
\hline M8 & $5.67 \pm 0.33$ & 100.00 & $14.00 \pm 0.00$ & 33.33 & $14.00 \pm 0.00$ & 66.67 & NR & 0.00 & $11.22 \pm 2.41$ & 50.00 \\
\hline
\end{tabular}

'*' Data are Mean \pm Standard error, $\mathrm{n}=15$; NR-No response

Table.6 Effect of BAP and IAA for Callus initiation from cotyledonary explants for different genotypes

\begin{tabular}{|c|c|c|c|c|c|c|c|c|c|c|}
\hline & \multicolumn{2}{|l|}{ G1 } & \multicolumn{2}{|l|}{ G2 } & \multicolumn{2}{|l|}{ G3 } & \multicolumn{2}{|l|}{ G4 } & \multicolumn{2}{|c|}{ Average of all genotypes } \\
\hline & $\begin{array}{l}\text { Days taken for } \\
\text { callus } \\
\text { initiation* }\end{array}$ & $\begin{array}{l}\text { Callus } \\
\text { initiation } \\
\text { response (\%) }\end{array}$ & $\begin{array}{l}\text { Days taken for } \\
\text { callus } \\
\text { initiation* }\end{array}$ & $\begin{array}{l}\text { Callus } \\
\text { initiation } \\
\text { response (\%) }\end{array}$ & $\begin{array}{l}\text { Days taken for } \\
\text { callus } \\
\text { initiation* }\end{array}$ & $\begin{array}{l}\text { Callus } \\
\text { initiation } \\
\text { response }(\%)\end{array}$ & $\begin{array}{l}\text { Days taken for } \\
\text { callus } \\
\text { initiation* }\end{array}$ & $\begin{array}{l}\text { Callus } \\
\text { initiation } \\
\text { response }(\%)\end{array}$ & $\begin{array}{l}\text { Days taken for } \\
\text { callus } \\
\text { initiation* }\end{array}$ & $\begin{array}{l}\text { Callus } \\
\text { initiation } \\
\text { response }(\%)\end{array}$ \\
\hline M1 & NR & 0.00 & NR & 0.00 & $12.00 \pm 0.82$ & 66.67 & NR & 0.00 & $12.00 \pm 0.00$ & 16.67 \\
\hline M2 & $15.50 \pm 0.41$ & 66.67 & $12.00 \pm 0.58$ & 100.00 & $6.33 \pm 0.33$ & 100.00 & $11.00 \pm 0.00$ & 66.67 & $11.21 \pm 1.89$ & 83.33 \\
\hline M3 & $17.00 \pm 0.00$ & 33.33 & $8.50 \pm 0.41$ & 66.67 & NR & 0.00 & $15.50 \pm 0.41$ & 66.67 & $13.67 \pm 2.27$ & 41.67 \\
\hline M4 & $16.00 \pm 0.00$ & 66.67 & $18.00 \pm 0.00$ & 33.33 & $13.33 \pm 0.33$ & 100.00 & $13.00 \pm 0.58$ & 100.00 & $15.08 \pm 1.18$ & 75.00 \\
\hline M5 & $9.00 \pm 0.58$ & 100.00 & $10.33 \pm 0.33$ & 100.00 & $9.33 \pm 0.33$ & 100.00 & $11.33 \pm 0.33$ & 100.00 & $10.00 \pm 0.53$ & 100.00 \\
\hline M6 & $13.50 \pm 0.41$ & 66.67 & NR & 0.00 & $17.00 \pm 0.82$ & 66.67 & NR & 0.00 & $15.25 \pm 1.24$ & 33.33 \\
\hline M7 & $17.33 \pm 0.33$ & 100.00 & $14.00 \pm 0.82$ & 66.67 & $16.50 \pm 0.41$ & 66.67 & NR & 0.00 & $15.94 \pm 0.87$ & 58.33 \\
\hline M8 & $15.00 \pm 0.00$ & 33.33 & $10.67 \pm 0.33$ & 100.00 & $11.00 \pm 0.58$ & 100.00 & NR & 0.00 & $12.22 \pm 1.21$ & 58.33 \\
\hline
\end{tabular}


Fig.1 In-vitro seed germination

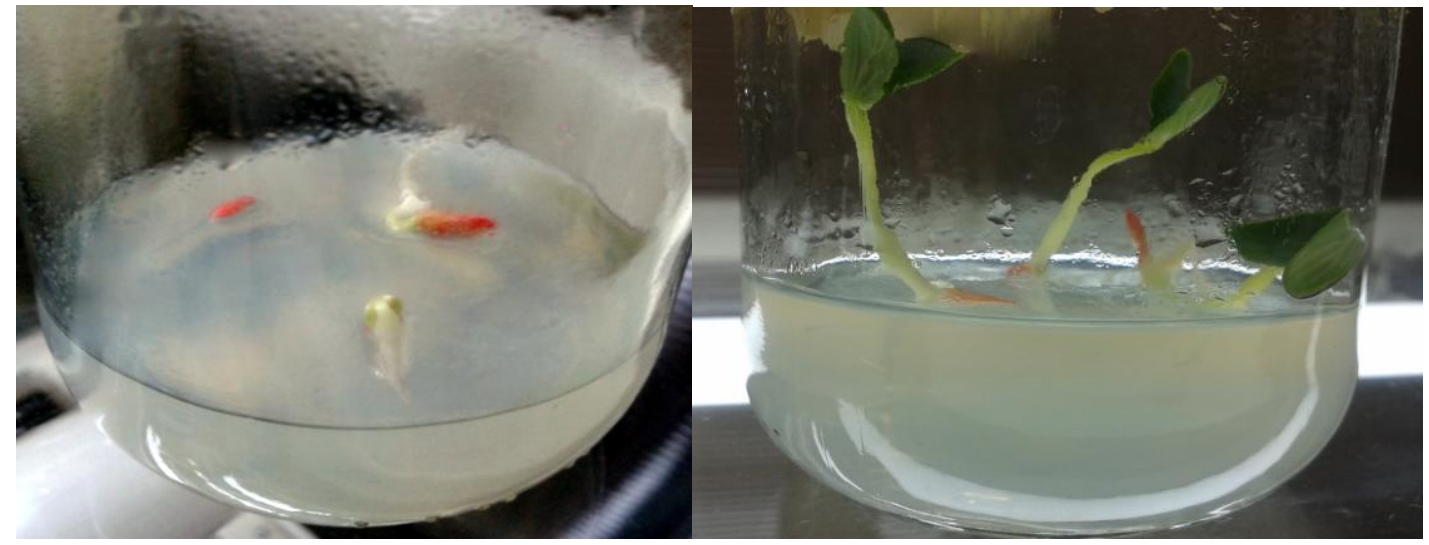

Fig.2 Shoot initiation from cotyledonary leaf explant

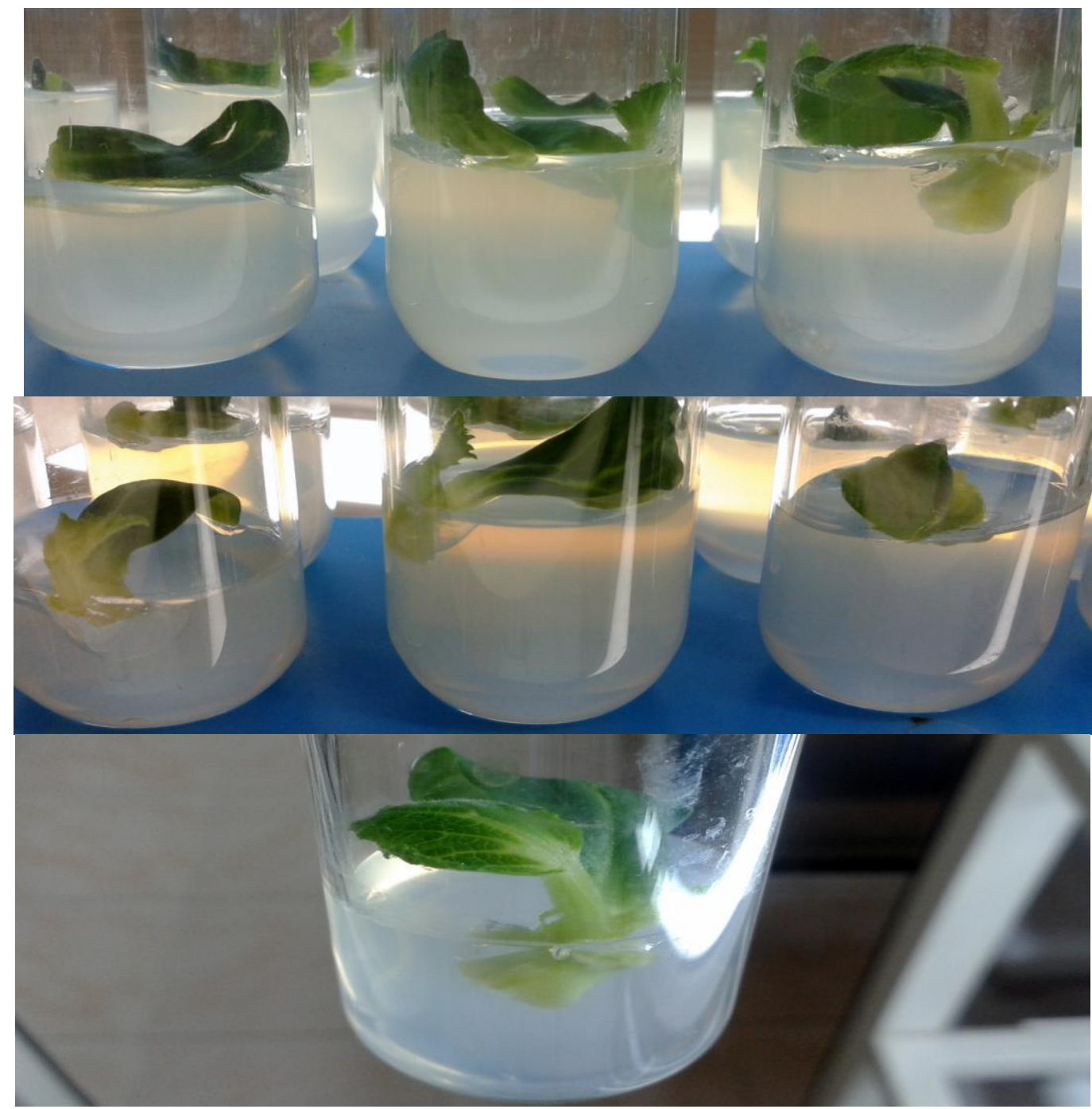


Fig.3 Root initiation from cotyledonary leaf explant

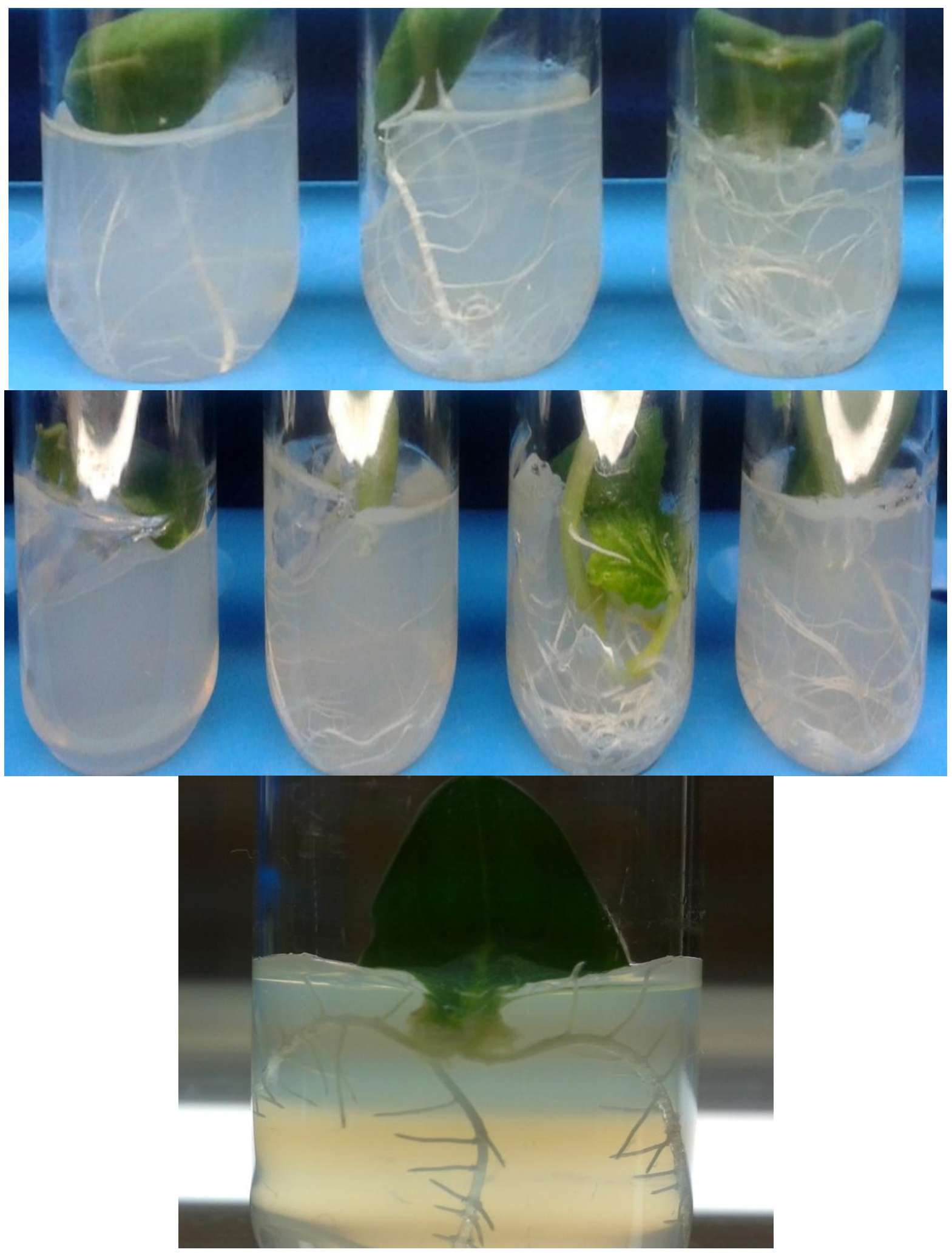


Fig.4 Callus initiation from cotyledonary leaf explants

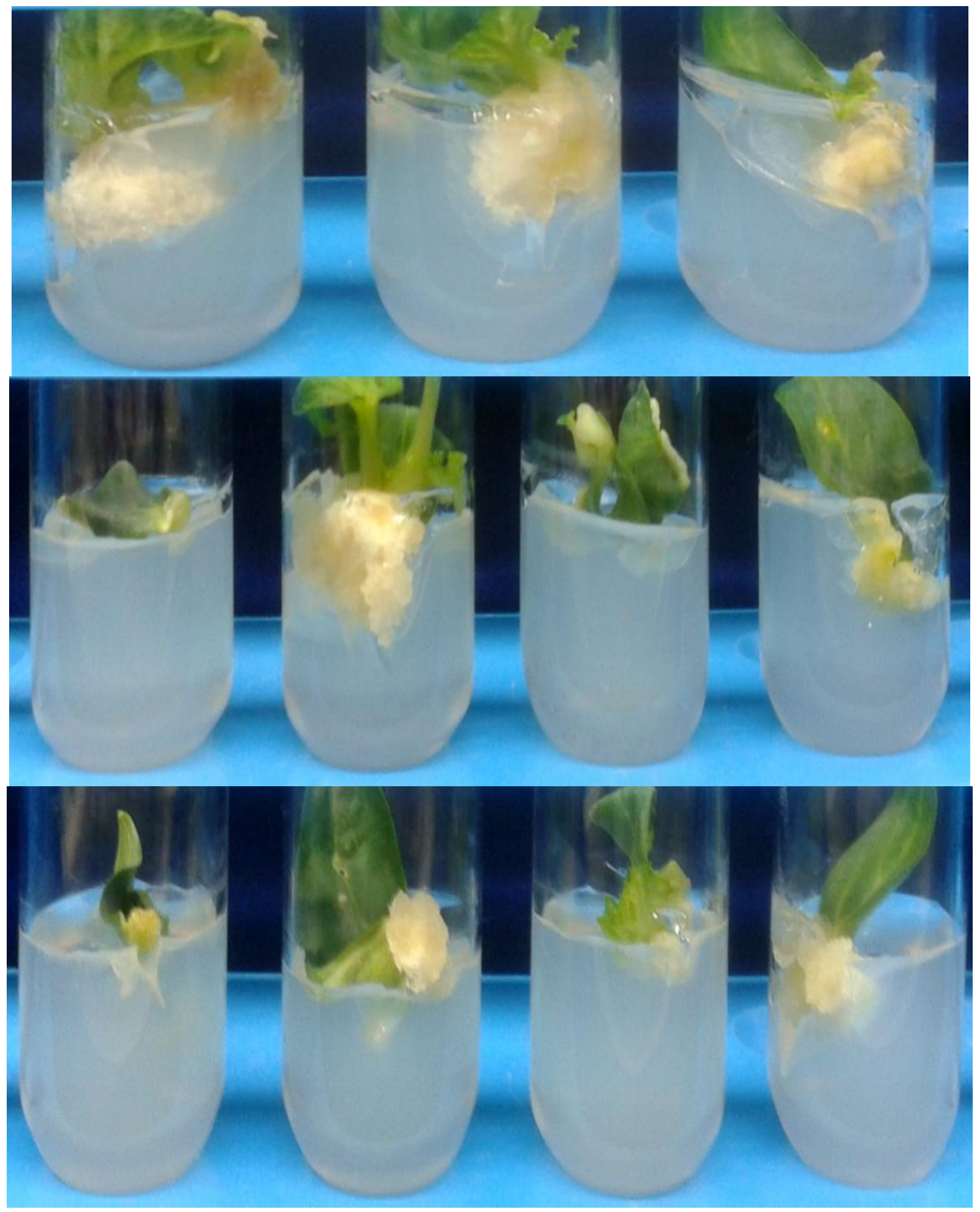

No response was observed in M1 and M6 media compositions for the genotype G2 and
M3 media composition for the genotype G3, respectively (Table 6). Four media 
compositions viz., M1, M6, M7 and M8 did not show any response for callus initiation in monoecious genotype (G4). Two media compositions, M5 (11.33 \pm 0.33$)$ followed by M4 (13.00 \pm 0.58$)$ had taken minimum number of days for callusing with 100 per cent response in the genotype G4.

On an average, irrespective of genotypes, M5 $(10.00 \pm 0.53)$ was the only media composition which had shown 100 per cent callusing with minimum days (Table 6).

In conclusion, it was found that different media compositions exhibited varying responses with all the genotypes. For shoot initiation, on an average, M8 media composition (Half MS + 0.5mg/l IAA + 2mg/l BAP) was found to be superior with respect to days taken for shoot initiation and response (\%) whereas for root initiation, M3 (Half MS $+0.25 \mathrm{mg} / \mathrm{l}$ IAA) was found to be better and for callus initiation, M5 media composition (Half MS $+0.25 \mathrm{mg} / 1 \mathrm{IAA}+2 \mathrm{mg} / \mathrm{l} \mathrm{BAP}$ ) was found to be the best. One can easily go for shooting, rooting and callusing phase by utilizing the above observed media compositions as an alternative for early and fast regeneration method to maintain and multiply various cucumber genetic stocks. With the advent of resulted media composition, we can reduce the cost of maintaining the parthenocarpic gynoecious genotypes as they lack male flowers for exvitro conditions and are supplied at high rates by private seed companies ranging from Rs. 4-10 per seed.

Ex vitro rooting, response in planting out and ultimate flower expression under various growing conditions are required to draw valid conclusions about the efficacy of the present media compositions.

Differential response of genotypes point towards the need for standardizing specific media for each cultivar and should be the initial step for breeding parthenocarpic, gynoecious cucumber hybrids.

\section{Acknowledgements}

We thank Dr. D. K. Singh (GBPUAT, Pantnagar) for providing the parthenocarpic genotypes. We also thank Kerala Agricultural University, Vellanikkara and UGC, New Delhi for providing the financial assistance for the PhD work.

\section{References}

Konstas, J. and Kintzios, S. 2003. Developing a scale-up system for the micropropagation of cucumber (Cucumis sativus L.): The effect of growth retardents, liquid culture and vessel size. Plant Cell Reports, 21: 538548.

Kumar, H.G.A., Murthy, H.N. and Paek, K.Y. 2003. Embryogenesis and plant regeneration from anther cultures of Cucumis sativus L. Scientia Hort., 98: 213-222.

Mahmoud, O. and Mokhtari, A. 2014. Rapid micropropagation of Cucumis sativus var. Dastgerdi (Iranian cultivar) by node culture technique. British Biotech. J., 4(6): 733-739.

Mohiuddin, A.K.M., Abdullah, Z.C., Chowdhury, M.K.U. and Napis, S. 2005. Enhancement of adventitious shoot regeneration in Cucumis sativus L. using AgNO3. Plant Tissue Cult., 15(1): 15-23.

Murashige, T. and Skoog, F. 1962. A revised medium for rapid growth and bioassays with tobacco tissue cultures. Physiol. Plant., 15: 473-477.

Stipp, L.C.L., Mendes, B.M.J., Piedade, S.M.D.S. and Rodriguez, A.P.M. 2001. In vitro morphogenesis of Cucumis melo var. inodorus. Plant Cell Tissue and Organ Cult., 65: 81-89. 
Ugandhar, T., Venkateshwarlu, M., Begum, G., Srilatha, T. and Reddy, J.K. 2011. In vitro plant regeneration of cucumber (Cucumis sativus L.) from cotyledon and hypocotyls explants. Sci. Res. Rep., 1(3): 164-199.

Usman, M., Hussain, Z. and Fatima, B. 2011. Somatic embryogenesis and shoot regeneration induced in cucumber leaves. Pak. J. Bot., 43(2): 1283-1293.
Wu, Z., Zhang, T., Li, L., Xu, J., Qin, X., Zhang, T., Cui, L., Lou, Q., Li, J. and Chen, J. 2016. Identification of a stable major-effect QTL (Parth 2.1) controlling parthenocarpy in cucumber and associated candidate gene analysis via whole genome re-sequencing. $B M C$ Plant Biol., 16:182, DOI 10.1186/s12870-016-0873-6.

\section{How to cite this article:}

Ajay Bhardwaj, T. Pradeepkumar and Varun Roch, C. 2017. In Vitro Regeneration of Parthenocarpic Cucumber (Cucumis sativus L.). Int.J.Curr.Microbiol.App.Sci. 6(7): 1711-1720. doi: https://doi.org/10.20546/ijcmas.2017.607.206 